Marquette University

e-Publications@Marquette

Philosophy Faculty Research and Publications

Philosophy, Department of

$10-1-2003$

\title{
Suicide Bombing: A Challenge to Just-War Theory and Natural Law
}

Howard P. Kainz

Marquette University, howard.kainz@marquette.edu

Accepted version. Human Rights Review, Vol. 5, No. 1 (October 2003): 72-76. DOI. (C) 2003 Springer. Used with permission.

Shareable Link. Provided by the Springer Nature SharedIt content-sharing initiative. 


\title{
Suicide Bombing: A Challenge to Just-War Theory and Natural Law
}

\author{
Howard Kainz \\ Department of Philosophy, Marquette University \\ Milwaukee, WI
}

During the last decade, with the advent of multiple acts of terrorism perpetrated by Al Qaeda and other global militant networks, it has become clear that classical just-war theory does not give very clear directives-even in the unlikely event that leaders of threatened peoples would care to consult JWT before determining their response! The traditional paradigm for JWT envisions a conclusion, by a threatened nation, that a hostile nation or hostile nations are gathering forces against it. This conclusion may be based either on clandestine intelligence or overt acts of aggression. Calculations are then made by the threatened nation: Is there a bona fide threat, or is it mere bluffing or chest-thumping? Have all diplomatic means been explored to defuse the threat? Will military defense possibly cause more damage than succumbing to the aggressors? Have proper procedures, in a democratic and constitutional system of government, been followed for engaging in war? Then, if these considerations for jus ad bellum have been satisfactorily answered, and hostilities are begun, subsequent questions about conduct during war, jus in bello, must be addressed: Noncombatants must be distinguished from combatants; prisoners of war must be dealt with in a just manner; pillaging, massacres, and torture must be avoided by the defending forces. 
Such ethical guidelines concerning war would be difficult or impossible to adhere to, in many contemporary situations. Terrorism rather than traditional war-making has become the strategy of choice by peoples or groups either unable to mobilize conventionally enough force, or possibly considering terrorism more effective, because of a "David vs. Goliath" military perspective. Terrorist attacks extend the idea of guerrilla warfare to its ultimate limits, "pulling out all stops" to confound, demoralize, defeat, and even exterminate the enemy. When terrorism is adopted as the strategy of choice, it is to the advantage of the terrorists to studiously avoid having any unified identifiable hostile force, or being situated in some specific geographical location, or even being linked with a specific nation. Forces that are organized, uniformed, and marching under a flag, and thus identifiable, are out of the question; weaponry (or the lack of it) must be a matter of guessing by the other side. And terrorist threats must always be as vague as possible, with no clear verifiable danger to the military forces of the enemy. The result optimally will be complete confusion by the enemy as to which specific civilian or military persons or groups on their side could be subject to attack, and need to be defended-no matter how just a defense would be. In other words, the imperative need to defend would be coupled with complete uncertainty as to what needs to be defended. But to defend everything is, of course, impossible.

In past decades, when the MAD strategy of the Cold War between the United States and the Soviet Union prevailed, the vague threats of total nuclear annihilation were thought to serve as a deterrent, on the presupposition that the enemy would be logical and non-suicidal. But this presupposition, if it ever made sense, can no longer be taken for granted. The clandestine leader of a terrorist nation or worldwide network might be willing to risk certain retaliation on his subjects or collaborators-and even himself. The consequences could be madness in a literal sense, extrapolated to global dimensions.

A complicating factor in trying to apply just war theory is that each side typically considers itself justified. But even if the jus ad bellum conditions could be satisfied for terrorists, it is unthinkable that jus in bello could be maintained. Random massacres of men, women, and children of a targeted group contradict instincts of justice and fairness in almost any moral and legal context. And the wholesale abandonment of considerations of justice becomes particularly acute in

Human Rights Review, Vol. 5, No. 1 (October 2003): pg. 72-76. DOI. This article is $\odot$ Springer and permission has been granted for this version to appear in e-Publications@Marquette. Springer does not grant permission for this article to be further copied/distributed or hosted elsewhere without the express permission from Springer. 
the case of suicide bombing. Occasionally apologists compare suicide bombing to heroic acts which sometimes take place in war, where a soldier will sacrifice his life, e.g. by falling on a live grenade, to save his comrades. But there is no similarity. The suicide bomber is not defending comrades, but participating in a nihilistic act of annihilation both for himself and his targets, which usually or frequently consist of noncombatants-even noncombatants who might sympathize with his or her cause.

When questions are raised about the morality of suicide bombing, justifications are given: These are acts of desperation by oppressed peoples, driven to extreme defensive measures; and, morality aside, there are supervening religious considerations, edicts and mandates by respected religious leaders who encourage and praise such acts as "martyrdom" leading to especially enticing heavenly rewards in the afterlife. And when confronted with the question of the murder of innocent noncombatants, the apologists for suicide bombing will often assert that in their special struggle, there are no "noncombatants." In the case of the Palestinian-Israeli conflict, the argument is that the enemy, Israel, is a militaristic country, completely mobilized, whose military "force" includes all males and females, young and old-all of whom perpetuate and assure, in various ways, according to their capacities, the oppression of Palestinians; even children are future combatants. Incidents against the United States, such as the massacre of September 11, 2001, are claimed to be ultimate and necessary extensions of the terrorist strategy-the U.S. being "fair game," since it is the ally offering indispensable support for Israel's continuing aggression. In short, the extermination of a whole population (the perpetrators would never use the term, "genocide") can be justified in this manner: Children are seen as future enemies to the existence and progress of the oppressed people; noncombatant adults and even the elderly can be portrayed as ideological proponents of further hostilities, or at the minimum as "fellow travelers"; and the constant threats of random acts of terror may interfere so drastically with normal living patterns and be so impermeable to ordinary military approaches, that the enemy will eventually leave the disputed territories willy-nilly.

The infractions of natural law in suicide-bombing strategy are almost intuitively obvious, requiring very little argument or painstaking theoretical applications: The most intuitively relevant principle, of

Human Rights Review, Vol. 5, No. 1 (October 2003): pg. 72-76. DOI. This article is @ Springer and permission has been granted for this version to appear in e-Publications@Marquette. Springer does not grant permission for this article to be further copied/distributed or hosted elsewhere without the express permission from Springer. 
course, is the "law of self-preservation," which inculcates a strong responsibility for maintaining one's own life, as well as the inalienable right to do so, and to continue living. It takes no great efforts at ratiocination to see that this law also implies a responsibility for not taking the life of others, as well as the right not to be threatened with extermination by others. The natural law of preserving the species is also relevant; it is certainly in the background of the general consensus of civilized people against genocide. A person who asks, "so, what's wrong with genocide (or "ethnic cleansing") is simply not on an ethical plane at all, and certainly manifesting symptoms of ethical imbecility. Finally the natural law of acting rationally, and extending this tendency to creating and maintaining rational social interrelationships, is probably the most important tenet of the natural law relevant to the case of suicide bombing, and the law most seriously threatened by the infractions of suicide bombers. Progress in the history of civilizations has only been possible by continual extensions of rational social interaction, superseding the inevitable dynamics of power, greed, aggrandizement, selfishness, and vanity.

Suicide bombing seems to constitute such an outrageous infraction of natural law that one wonders how fellow humans, sharing the same nature, could possibly embrace it in all its nihilistic overtones. Natural-law arguments, and any universal moral considerations, are relevant as challenges to politically-motivated suicide bombers, such as the Tamil separatists in Sri Lanka or the female resistance fighters in Chechnya. But morality is considered irrelevant by those who feel they have a religious mandate to commit such acts, such as Islamicist proponents of suicide bombing-including even many Muslim academicians. In a tradition like the modern Western tradition, which recognizes the distinction between ethics and religion, and the distinction between politics and religion, an ethicist might get a hearing. But in the eyes of the strict Islamicists who defend suicide bombing, there is no such distinction. Islamic law, sharia, is final and complete for all time. There is no code of ethics which can supplement it; no national or international laws valid in their own right, simply as a result of rational deliberation and agreement; no political power separate and distinct from religious authority, and capable of coordinating and protecting rights of a variety of religious persuasions. In short, suicide bombing is a crystal-clear example of the problem of a theocracy which becomes identical with morality, law,

Human Rights Review, Vol. 5, No. 1 (October 2003): pg. 72-76. DOI. This article is $@$ Springer and permission has been granted for this version to appear in e-Publications@Marquette. Springer does not grant permission for this article to be further copied/distributed or hosted elsewhere without the express permission from Springer. 
and politics. If the tenets of this theocracy are irrational and immoral, this is not an argument against it; it is not subject to reexamination or criticism based on rational considerations.

In the context of Western philosophy and ethics, the problem of suicide bombing can best be considered as a subset of the larger problem of the relationship of ethics to religion and vice versa: Does a religion have a right to enjoin acts which are irrational and immoral? Or does the religious person have the converse right-even a Godgiven right-to analyze the tenets of a religion for conformity to reason, and to resolutely discountenance any religious directives which go clearly against reason and ethics? Historically, and even at present, religions have justified or even recommended blatant infractions of the natural law-child sacrifice, female genital mutilation, cannibalism, ritual suicide of widows, as well as genocidal destruction of all other religions. If such practices are authoritatively justified by a religion, and not just attributable to the excesses of individuals, can and should a rational observer come to the conclusion that that religion is ipso facto invalid, not divinely inspired, but to be resolutely avoided and discountenanced?

The locus classicus for this problematic in the Judaeo-Christian tradition is of course the case in Genesis 22:2, in which Yahweh commands Abraham to slay his son, Isaac, and Abraham unquestioningly prepares to perform the act, being prevented only by a divinely-sent last-minute angelic reprieve. Jewish and Christian philosophers and theologians have wrestled for over two millennia with this story and their responses range from Kant's rejection of the authenticity of the story (since of course God would never command anything unethical like murder) to Kierkegaard's interpretation in terms of the "teleological suspension of the ethical" by faith (leading to a relativization of even ethics and rationality in face of the absolute divine "paradox"). Thomas Aquinas, most of whose life-long efforts were directed at showing the compatibility of faith and reason, in response to the objection that God's command to kill Isaac is against the natural law, answers that such a situation would be a "limiting case" for natural law: if God, the author of nature and life, commands someone to be killed, it is no longer unnatural or immoral; he argues in the same vein regarding other Old Testament narratives in which God commands the Israelites to steal from the Egyptians (Exodus

Human Rights Review, Vol. 5, No. 1 (October 2003): pg. 72-76. DOI. This article is @ Springer and permission has been granted for this version to appear in e-Publications@Marquette. Springer does not grant permission for this article to be further copied/distributed or hosted elsewhere without the express permission from Springer. 
12:35), or commands Osee to commit adultery (Osee $1: 2$ ) (See the Summa theologiae I-II, q. 94, a. 5, ad 2).

Even if we agree with Aquinas about the supervening morality of a divine command, the ultimate question that arises would be, does God really command it? In a previous work, I have argued that a valid religious command must pass ethical muster, and that cases such as Abraham's willingness to sacrifice Isaac must be understood in terms of the evolution of conscience in ancient times (see Ethics in Context, Georgetown University Press, 1988, p. 122), which might have involved the unconscious projection of divine mandates. In any case this may be a challenge strictly relegated to the individual level, defying any ethical universalization, a question that must be dealt with only rarely by individual prophets or seers-such as Abraham, Joshua, Osee, Mohammed, Joan of Arc, Joseph Smith, or (in recent decades) the six young people in Medjugorje who claim to have had frequent messages from the Virgin Mary. To them, conscience should suggest, "is this from God, or from my overactive imagination or my personal agenda?"

Moving from the individual situation to the more universal question: what defense can sincere believers (and the human race) have against false prophets and mindless religious authorities that claim to be passing on a command from God to kill, for example, all the members of a certain ethnic group, or religion, or to carry out other abominable acts? Certainly the "grammar of assent" for religious commitment would include a more than cursory examination of natural law. And if there are degrees of unnaturalness and immorality, certainly a religion whose recognized authorities preach "kill, kill, kill" has gone beyond the possible parameters of the individual exceptions Aquinas defends, and must be rejected by any thinking person.

A major danger is that we who consider ourselves tolerant and broadminded should come to view suicidal acts splattering all bystanders to pieces as just one more legitimate expression of religious faith-an act given extra legitimation by stressful political and military realities. The shudder that we feel in extending this line of thought to its limits is normal, understandable, nothing to be ashamed of, a sign that religion and sanity are not contradictory.

Human Rights Review, Vol. 5, No. 1 (October 2003): pg. 72-76. DOI. This article is @ Springer and permission has been granted for this version to appear in e-Publications@Marquette. Springer does not grant permission for this article to be further copied/distributed or hosted elsewhere without the express permission from Springer. 